\title{
IMPLEMENTASI PRINSIP BAGI HASIL DAN RISIKO DI PERBANKAN SYARIAH
}

\author{
(Studi di Perbankan Syariah Cabang Mataram)
}

FATAHULLAH, SH.

\begin{abstract}
ABSTRAK
Indonesia merupakan Negara dengan jumlah penduduk muslim terbesar di dunia, akan tetapi penerapan nilai nilai Islam secara Kaffah dan utuh dalam kehidupan sehari hari belum dilaksanakan seutuhnya. Misalnya dalam lembaga keuangan perbankan, perbankan syariah di Indonesia baru muncul pada tahun 1992 ketika di sahkannya Undang undang No 7 Tahun 1992 tentang Perbankan dalam Undang undang ini mulai mengakomodir perbankan syariah dengan nama perbankan bagi hasil, selanjutnya diganti dengan Undang undang No. 10 Tahun 1998.

Permasalahan yang dihadapi adalah bagaimana implementasi prinsip bagi hasil dan risiko dalam kegiatan penghimpunan dana, implementasi prinsip bagi hasil dalam kegiatan pembiayaan di perbankan syariah Mataram dan apa yang menjadi kendala operasional yang dihadapi dalam implementasi prinsip bagi hasil hasil tersebut.

Penelitian ini menggunakan metode pendekatan doktrinal dan non doktrinal atau socio legal yakni memandang hukum bukan saja teks dalam Undang undang akan tetapi juga melihat hukum berinteraksi dengan masyarakat.

Salah satu prinsip usaha Perbankan Syariah adalah akad Bagi Hasil dan resiko dimana bank dan nasabah membagi keuntungan berdasarkan rasio Bagi Hasil yang ditentukan sebelumnya. Fungsi perbankan adalah sebagai lembaga perantara (intermediary institution) antara pemilik dana dan orang yang membutuhkan dana, untuk itu kegiatan utama Perbankan Syariah adalah menghimpun dana dari masyarakat dan menyalurkan kembali dalam bentuk pembiayaan. Kegiatan penghimpunan dana di Perbankan Syariah Mataram dilakukan dengan prinsip wadiah dan mudharabah, beberapa produknya seperti Giro BSM Dollar Singapura, Giro BSM, Giro BSM Valas, Giro BSM OURO, giro wadiah bank Muamalat dalam mata uang Rupiah maupun Valas, pribadi maupun perusahaan, tabungan umat junior, tabungan simpatik. Sedangkan mudharabah seperti: Tabungan Haji, Tabungan Investa Cendekia, Tabungan Qurban dan Tabungan dengan Kartu SharE, deposito BSM, deposito BSM Valas dan Deposito Mudharabah. Sedangkan penyaluran dana dalam bentuk pembiayaan Bagi Hasil adalah dengan akad mudharabah dan musyarakah. Prinsip Bagi Hasil ini merupakan karakteristik utama dalam Perbankan Syariah, akan tetapi dalam kegiatan pembiayaan di Perbankan Syariah masih rendah di bandingkan dengan pembiayaan lainnya seperti Murabahah (jual beli), hal ini disebabkan antara lain karena tingginya resiko yang harus di tanggung oleh bank apabila terjadi kerugian yang di akibatkan bukan dari kesengajaan atau kelalaian dari nasabah sehingga bank akan sangat berhati hati dalam memberikan pembiayaan kepada nasabah. Kendala lainnya adalah Sumber daya Manusia yang kurang memadai, manajemen perbankan syariah, system informasi dan teknologi, sikap masyarakat yang
\end{abstract}


masih memandang Bank Syariah sama dengan bank Konvensional dan tidak adanya standar moral yang diterapkan dalam kegiatan pembiayaan.

\section{Kata kunci: Perbankan Syariah, Implementasi, Bagi Hasil, dan Risiko.}

\section{Latar Belakang}

Pergeseran kebijakan ekonomi nasional yang mengikuti perkembangan ekonomi global telah membuat pemerintah untuk membenahi kegiatan-kegiatan ekonominya. Salah satu kegiatan ekonomi yang dibenahi tersebut adalah kegiatan perbankan karena perbankan merupakan kegiatan yang penting dalam menunjang kegiatan pembangunan nasional. Intrumen hukum yang dibenahi adalah dikeluarkannya Undang undang No 7 Tahun 1992 tentang Perbankan. Dalam Undang unndang ini mulai diakomodasi perbankan islam dengan nama perbankan bagi hasil, yang kemudian direspon oleh Umat Islam yang diwakili oleh Majelis Ulama Indonesia dan Organisasi kemasyarakatan dengan membentuk Bank Muamalat Indonesia (BMI). Bank inilah yang merupakan bank umum islam pertama yang menerapkan sistem bagi hasil yang berbeda dengan sistem perbankan yang selama di kenal oleh masyarakat Indonesia. Hadirnya BMI ini merupakan jawaban tersendiri bagi umat islam yang menginginkan transaksi yang bebas riba yang ada di bank konvensional, bank syariah dirasakan terlambat dibandingkan dengan bank bank Islam lainnya di negara negara lainnya seperti Malaysia, Pakistan dan negara negara teluk lainnya.

Sudah cukup lama ummat Islam Indonesia, dan belahan dunia lainnya, menginginkan perekonomian yang berbasis pada nilai-nilai dan Prinsip Syari'ah untuk dapat diterapkan dalam segala aspek kehidupan dan dalam transaksi antar ummat yang didasarkan pada aturan-aturan Syari'ah. Keinginan ini didasari oleh kesadaran untuk menerapkan Islam secara utuh dalam segala aspek kehidupan, sebagaimana dijelaskan dalam surah Al-Baqarah ayat (208) yang artinya sebagai berikut: "Hai orang-orang yang beriman, masukklah kamu kedalam Islam secara kaffah (utuh/menyeluruh). Ayat ini dengan tegas mengingatkan kepada ummat Islam untuk melaksanakan Islam

\footnotetext{
${ }^{1}$ Surah Al-Baqarah Ayat 85 dan 208, Al-Qur'an dan Terjemahannya, Karya Toha Putra, Semarang, 1995.
} 
secara kaffah bukan secara parsial, Islam tidak hanya diwujudkan dalam bentuk ritualisme ibadah semata, dan dimarginalkan dari dunia politik, ekonomi, perbankan, asuransi, pasar modal, pembiayaan proyek, transaksi ekspor-impor dan lain-lain, apabila hal ini terjadi, maka ummat Islam telah menjauhkan Islam dari kehidupannya.

Berdasarkan hasil penelitian Bank Indonesia ${ }^{2}$ masih terdapat masyarakat yang enggan berhubungan dengan bank sebagai akibat dari diterapkannya sistem bunga yang diyakini sebagai riba yang diharamkan. Oleh karena itu dibutuhkan suatu konsep alternatif sistem perbankan yang dapat menampung tuntutan dan kebutuhan masyarakat, dengan sistim bagi hasil dan resiko (profit and loss sharing), yang mengedepankan prinsip keadilan dan kebersamaan dalam berusaha, baik dalam memperoleh keuntungan maupun dalam menghadapi resiko.Bukti konkrit yang perlu diambil ibroh (pelajaran) ketika bunga diterapkan oleh perbankan konvensional, sehingga bangsa Indonesia mengalami krisis ekonomi dan moneter yang memporakporandakan sendi-sendi kehidupan bangsa, yang pada akhirnya Indonesia sangat terpuruk dalam berbagai sektor kehidupan. Salah satu sektor yang sangat mencengangkan adalah ketika perbankan konvensional dengan sistim bunganya mengalami kebangkrutan sejak tahun 1997, tidak kurang sekitar 30 bank ditutup atau dilikuidasi dan selanjutnya ada 55 bank masuk dalam kategori pengawasan oleh BPPN. Untuk membantu bank bank tersebut pemerintah terpaksa membantu dengan mengucurkan bantuan kredit yang dikenal dengan Bantuan Likuiditas Bank Indonesia (BLBI) yang sampai sekarang belum dapat dapat di lunasi oleh kreditornya.

Kondisi ini sangat berbeda dengan perbankan yang beroperasi sesuai dengan prinsip Syari'ah, hal ini disebabkan karena bank syari ah tidak dibebani membayar bunga simpanan nasabah. Bank syari ah hanya membayar bagi hasil yang jumlahnya sesuai dengan tingkat keuntungan perbankan syari ah. Dengan sistem bagi hasil tersebut, maka jelas bank-bank syari ah selamat dari negative spread. Bank syariah bukannya ikut ambruk sebagaimana halnya perbankan konvensional pada umumnya, malahan krisis ekonomi dan moneter justru telah membawa dampak yang positif bagi

\footnotetext{
${ }^{2}$ Hasil Penelitian Bank Indonesia, tentang Potensi dan Preferensi bank Syari'ah di Jawa Barat, Jawa Tengah dan Jawa Timur, Tahun 1999
} 
perkembangan bank Syari'ah. Sampai dengan tahun 2007 jumlah bank umum syariah adalah 3 buah, unit usaha syariah sebanyak 24 buah dan BPRS sebanyak 105 buah.

Di balik perkembangan bank syariah yang secara kuantitas semakin berkembang, tetapi dalam pelaksanaanya, prinsip dasar dalam kegiatan perbankan syariah yaitu sistem bagi hasil kurang di minati dalam kegiatan pembiayaan perbankan syariah. Pembiayaan mudharabah dan musyarakah secara nasional pada tahun 2003 hanya sebesar 20,3\% (persen) bila di bandingkan dengan pembiayaan murabahah (jual beli) yang sebesar 71, 2 \% (persen), dari total pembiayaan sebesar 5, 47 Trilyun. Dari segi asset, jika pada tahun 2000 asset perbankan syariah baru mencapai 1,2 triliun, namun pada November 2004 meningkat menjadi 14 triliun. Demikian juga dengan dana pihak ketiga (DPK) dari 669 miliar pada tahun 2000, kemudian meningkat menjadi 10,4 triliun pada November 2004, atau 1,1 persen dari total aset perbankan nasional yang mencapai 1.000 triliun rupiah. ${ }^{3}$

Secara teoritis prinsip bagi hasil dan resiko merupakan inti atau karakteristik utama dari kegiatan perbankan syari'ah. Akan tetapi dalam kegiatan pembiayaan bagi hasil dan resiko produk musyarakah dan mudharabah kurang di minati dalam kegiatan pembiayaan, hal ini bisa dilihat dari data diatas. Hal ini disebabkan oleh karena tingkat resiko pembiayaan mudharabah dan Musyarakah sangat tinggi (hight risk) dan pengembaliannya tidak pasti, padahal bank merupakan lembaga bisnis, lembaga lembaga intermediasi dimana bank berfungsi sebagai perantara pihak yang kekurangan modal (lack of fund) dan pihak lain yang kelebihan modal (surplus of fund), disamping itu bank juga harus mengembalikan dana nasabah penabung setiap saat. Semestinya bank dengan nasabah harus memahami betul tentang filosofi pembiayaan dengan sistem mudharabah dan Musyarakah, karena Islam memberikan solusi yang adil bagi kedua belah pihak dengan prinsip pertanggung jawaban yang jelas, bukan hanya ingin mendapatkan keuntungan sendiri sementara pihak yang lain mengalami kerugian

\section{Permasalahan}

\footnotetext{
${ }^{3}$ Kumpulan Artikel BNI Syariah, Peluang dan Tantangan Bank Syariah di Indonesia. Al Kautsar Prima. 2006. hal 47
} 
a. Bagaimana implementasi prinsip bagi hasil dan resiko dalam kegiatan penghimpunan dana di perbankan syariah Mataram?

b. Bagaimana implementasi prinsip bagi hasil dan resiko dalam kegiatan pembiayaan di perbankan syariah Mataram?

c. Apa saja yang menjadi kendala operasional yang8 dihadapi dalam implementasi prinsip bagi hasil dan resiko di Perbankan Syariah Mataram?

\section{Landasan Teori}

Kehadiran hukum ditengah masyarakat merupakan upaya perlindungan terhadap hak hak masyarakat terhadap tindakan sewenang wenang dari orang yang berkuasa. Hukum hadir untuk mengatur kehidupan masyarakat agar terjadi keseimbangan antara hak dan kewajiban. Hukum yang baik adalah hukum yang sesuai dengan kultur dan budaya masyarakat yang diaturnya. Hukum yang tidak mencerminkan kultur dan kebutuhan masyarakat kemudian dipaksakan berlaku atau sering disebut sebagai teori Fiksi dimana masyarakat dianggap tahu tentang hukum hanya akan melahirkan hukum yang tidak efiktif dan efisien karena tidak dipatuhi dan dilaksanakan oleh masyarakat sebagai objek hukum.

Satjipto Rahardjo, mengatakan bahwa ada dua macam fungsi hukum yang berdampingan satu sama lain adalah: ${ }^{4}$

a. fungsi hukum sebagai sarana pengendalian sosial, dan

b. sabagai sarana untuk melakukan social engineering

Fungsi hukum sebagai sarana pengendalian sosial yaitu hukum sekedar menjaga agar setiap orang menjalankan peranannya sebagaimana yang telah ditentukan atau di harapkan. Perubahan social yang terjadi akan berpengaruh pula terhadap bekerjanya mekanisme pengendalian sosial ini $^{5}$. Sedangkan fungsi hukum sebagai sarana untuk melakukan rekayasa sosial (merubah masyarakat) yakni di sini hukum tidak hanya dipakai untuk mengukuhkan pola pola kebiasaan dan tingkah laku

\footnotetext{
${ }^{4}$ Satjipto Rahardjo, Pemanfaatan Ilmu Sosial bagi Pemanfaatan Ilmu Hukum, Alumni, Bandung. 1977. Hal 143.

${ }^{5}$ Ibid, hal 143
} 
yang terdapat dalam masyarakat, melainkan juga untuk mengarahkan kepada tujuan tujuan yang dikehendaki, menghapuskan kebiasaan yang di pandang tidak sesuai lagi, menciptakan pola pola kelakuan baru' ${ }^{6}$. Penggunaan hukum untuk melakukan perubahan perubahan dalam masyarakat berhubungan erat dengan konsep penyelenggaraan kehidupan sosial ekonomi dalam masyarakat.

Islam sebagai ajaran yang universal dan integral, telah mengatur segala aspek kehidupan manusia, baik di bidang sosial, budaya, politik, hukum, pertahanan keamanan maupun bidang ekonomi dan keuangan. Seiring dengan berkembangnya nilai-nilai Islam di tengah masyarakat setelah runtuhnya ajaran komunisme yang berpusat di Sovyet pada tahun 1990-an, sehingga Samuel Paul Hantington menyatakan bahwa setelah komunis runtuh ancaman bagi negara-negara barat adalah peradaban Islam ${ }^{7}$.

Tujuan utama Syari' at diturunkan adalah untuk kemaslahatan (kebaikan) dan mencegah kemafsadatan (kerusakan), Syari'at menetapkan ada lima kebutuhan pokok manusia yang harus dilindungi oleh hukum, yaitu; ${ }^{8}$ agama, jiwa, harta, akal, dan keturunan, sehingga Allah SWT menjadikan risalah Nabi Muhammad SAW sebagai rahmatan lil alamiin sebagaimana tercermin dalam surah Al-Anbiya ayat 107 yang artinya; "Tidaklah kami mengutus engkau, kecuali menjadi rahmat begi seru sekalian alam”.

Berdasarkan uraian di atas, maka untuk memahami dan mendeskripsikan permasalahan dalam penelitian ini, maka akan didasarkan pada teori aksi (action theory) yang dicetuskan oleh Max Weber. Teori aksi sebagaimana kedua teori lainnya (teori interaksionisme simbolik (simbolik interaksionism) dan fenomenologi $($ phenomenology $))^{9}$. Ketiga teori ini mendasarkan pada suatu ide dasar, yaitu :

1. manusia adalah merupakan aktor yang aktif dan kreatif dari realitas sosial;

\footnotetext{
${ }^{6}$ Satjipto Rahardjo, Ilmu Hukum, Alumni, Bandung. 1982. Hal 169

${ }^{7}$ Yusuf Al-Qardawi, Umat Islam Menyongsong Abad Ke-21, Era Intermedia, Solo, 2001 hal 330-335).

${ }^{8}$ Daud Rosyid, Indahnya Syari'at Islam, Usamah Press, Jakarta, 2003, hal 35.

9 George Ritzer, Sosiologi Ilmu Pengetahuan Berparadigma Ganda, Penerjemah: Alimandan, RajaGrafindo Persada, Jakarta, 1992, hal. 49.
} 
2. realitas sosial bukan merupakan alat yang statis daripada paksaan fakta sosial. Artinya tindakan manusia tersebut tidak sepenuhnya ditentukan oleh normanorma, kebiasaan-kebiasaan, nilai-nilai dan sebagainya yang kesemuanya itu tercakup dalam konsep fakta sosial;

3. manusia mempunyai cukup banyak kebebasan untuk bertindak diluar batas kontrol dari fakta sosial ${ }^{\mathbf{1 0}}$.

Sebagai pencetus teori aksi, Max Weber menempatkan konsep tindakan individual yang bermakna pada pusat teorinya tentang masyarakat. Konsep tersebut menekankan bahwa realitas sosial tidaklah berwujud secara obyektif. Kehidupan sosial, secara rumit dibentuk oleh kultur dan makna, karena para pelaku menggunakan pengetahuan mereka, untuk menyesuaikan diri dan mengubah dunia, di mana mereka menjadi bagiannya. ${ }^{\mathbf{1 1}}$ Walaupun manusia tidak mempunyai kebebasan total, karena adanya pembatasan dari berbagai tujuan yang hendak dicapai, kondisi dan norma, serta situasi penting lainnya, tetapi aktor mempunyai kemauan bebas dalam memilih berbagai alternatif tindakan. Kemampuan inilah yang oleh Talcott Parsons disebut sebagai voluntarism (kesukarelaan), yaitu kemampuan individu melakukan tindakan, dalam arti menetapkan cara atau alat dari sejumlah alternatif yang tersedia dalam rangka mencapai tujuannya. ${ }^{\mathbf{1 2}}$

Bagi hasil menurut terminologi asing (Inggris) dikenal dengan profit sharing. Profit sharing dalam kamus ekonomi di artikan sebagai laba. Secara definitif profit sharing di artikan distrubusi beberapa bagian dari laba pada para pegawai dari suatu perusahaan $^{13}$. Pada mekanisme lembaga keuangan syariah pendapatan bagi hasil ini berlaku untuk produk produk penghimpunan dan penyertaan modal, baik penyertaan menyeluruh maupun sebagian atau bentuk bisnis korporasi (kerjasama). Keuntungan yang dibagi hasilkan harus di bagi secara proporsional antara shahibul maal dengan mudharib sesuai dengan proporsi yang disepakati sebelumnya.

\footnotetext{
${ }^{10}$ Op. Cit, hal. 50

11 Robert W Hefner, Geger Tengger : Perubahan Sosial Dan Perkelahian Politik, LKIS bekerjasama dengan The Asia Foundation, Yogyakarta, 1999, hal. xiv.

${ }^{12}$ George Ritzer, Op.Cit. hal. 57

${ }^{13}$ Muhammad, Tehnik Perhitungan Bagi Hasil di Bank Syariah, UII Press, Yogyakarta, 2001, Hal. 22
} 
Dalam sistem ekonomi Islam, tingkat bunga yang dibayarkan bank kepada nasabah (deposan) diganti dengan persentase atau porsi bagi hasil, dan tingkat bunga yang diterima oleh bank (dari debitur) akan diganti dengan persentase bagi hasil. Dua bentuk rasio keuntungan di jadikan instrumen untuk memobilisasi tabungan dan disalurkan pada aktivitas aktivitas bisnis produktif. Walaupun para ahli ekonomi muslim menekankan bahwa ada kekuatan built-in dalam sistem ekonomi Islam dalam menjamin stabilitas. Oleh karena itu mereka berpendapat bahwa dalam mekanisme bagi hasil tidak akan ada faktor yang menyebabkan terjadinya ketidakstabilan ekonomi. Nejatullah Siddiqi melakukan analisis terhadap perilaku bagi hasil terhadap kondisi stabilitas ekonomi, bahwa: "the introduction of ratios of profit sharing to replace rate of interest will not destabilize the economy and that the change in the entrepreneural profit will not get communicated back all along the line" ${ }^{14}$. pernyataan ini menetapkan bahwa sistem ekonomi berdasarkan bagi hasil akan menjamin alokasi sumber ekonomi yang lebih baik dan terjadinya distribusi pendapatan yang lebih sesuai. Analisis terhadap persoalan peran bagi hasil terhadap ppencapaian stabilitas ekonomi harus dengan menggunakan pendakatan analisis keseimbangan (equilibrium). Mekanisme analisis keseimbangan menyajikan bagaimana mekanisme penentuan supply dan deman atas tabungan.

Dasar hukum pelaksanaan perbankan syariah di Indonesia terbagi dalam dua bagian yaitu dasar hukum normatif dan dasar hukum formal. Keduanya secara simultan memberikan kekuatan hukum berlakunya perbankan syariah di Indonesia. Dasar hukum normatif berasal dari hukum Islam yabg bersumber dari Al Qur'an, Sunnah dan Ijtihad. Ketentuan ini akan dikeluarkan dalam bentuk Fatwa Dewan Syariah Nasional. Kekuatan mengikat fatwa itu bersifat normatif, artinya fatwa itu hanya mengikat, pertama bagi yang mengeluarkan atau yang mengfatwakannya, dan kedua mengikat bagi yang menerimanya atau yang menundukan diri atas fatwa itu ${ }^{15}$. Karena sifat dan kekuatannya seperti itu, maka berlakunya belum secara mutlak bagi seluruh umat Islam. Berbeda halnya jika ketentuan itu langsung dari Al Qur'an dan Sunnah, secara otomatis langsung mengikat bagi umat islam di Indonesia. Hukum

${ }^{14}$ ibid, Hal 27

${ }^{15}$ H.M. Arifin Hamid, Hukum Ekonomi Islam (Ekonomi Syariah) Di Indonesia, Ghalia Indonesia, Bogor, 2007, Hal. 134 
Islam yang terbangun dari dari sumber yang pokok dan terbentuk dari proses ijtihad merupakan norma atau kaidah hukum yang hanya memiliki kekuatan mengikat jika di akui, diterima, dan di laksanakan oleh umat Islam sesuai dengan tingkat kesadaran dan keimanannya. Sedangkan dasar hukum formal merupakan ketentuan yang telah melalui proses positivisasi atau formalisasi oleh Negara melalui lembaga Legislatif dan Bank Indonesia sebagai lembaga yang memiliki otoriter terhadap Perbankan Indonesia.

Dasar hukum peraturan perundang undangan nasional

1. Pancasila sila pertama Ketuhanan Yang Maha Esa

2. UUD 1945 pasal 29

3. Undang undang Nomor 7 Tahun 1992 tentang Perbankan yang di ubah dengan Undang undang Nomor 10 Tahun 1998 tentang perbankan

4. peraturan Bank Indonesia Nomor 6/24/PBI/2004 tertanggal 14 oktober 2004 tentang Bank Umum yang melaksanakan kegiatan usaha berdasarkan prinsip syariah. Dan untuk BPRS yaitu Peraturan Bank Indonesia Nomor 6/17/PBI/2004 tanggal 1 juli 2004 tentang Bank Perkreditan Rakyat Syariah.

\section{Metode Penelitian}

\section{1. metode pendekatan}

Penelitian ini mendasarkan pada penelitian hukum yang dilakukan dengan pendekatan doktrinal atau normatif yang memandang hukum sebagai separangkat aturan atau kaidah yang bersifat normatif, dan pendekatan non doktrinal atau pendekatan sosiologis. Hal ini disebabkan karena di dalam penelitian ini, hukum tidak hanya diartikan atau dikonsepkan sebagai keseluruhan asas-asas dan kaidahkaidah yang mengatur kehidupan manusia dalam masyarakat, melainkan meliputi pula lembaga-lembaga dan proses yang mewujudkan berlakunya. Jadi pendekatan yang digunakan dalam penelitian ini adalah pendekatan Yuridis empiris, yaitu yang memandang hukum bukan saja sebagai seperangkat kaidah yang bersifat normatif atau apa yang menjadi teks Undang-Undang (law in books), akan tetapi juga melihat bagaimana hukum berinteraksi dengan masyarakat (law in action). Sehubungan dengan permasalahan yang diangkat adalah implementasi prinsip 
bagi hasil dan resiko di perbankan syariah maka diharapkan akan diperoleh pemahaman yang integral dari aspek hukum baik hukum Islam maupun hukum nasional.

\section{2. sumber data}

Penelitian ini membutuhkan dua jenis data yang berasal dari sumber yang berbeda yaitu:

a. Data Primer, yaitu data-data yang berasal dari sumber data utama, yang berwujud tindakan sosial, kata-kata dari pihak yang terlibat dengan dan/atau di dalam pendirian dan pengelolaan Bank Syari'ah. Data primer ini akan diperoleh melalui informan pada situasi sosial tertentu yang di pilih secara purposive, dengan menentukan informan dan situasi sosial awal terlebih dahulu. Penentuan informan, dilakukan terhadap beberapa informan yang memenuhi kriteria sebagai berikut: (1). mereka yang memahami dan menguasai permasalahan perbankan syari' ah baik dari aspek hukum Islam maupun hukum nasional, (2). mereka yang sedang terlibat dengan (di dalam) kegiatan pengelolaan perbankan syari'ah.

b. Data sekunder, yaitu data yang berasal dari bahan bahan pustaka, yang meliputi dokumen dokumen tertulis, yang bersumber dari peraturan perundang undangan (hukum positif di Indonesia), maupun Al Qur'an, Hadist, Ijma dan Qiyas para Ulama yang merupakan sumber hukum dalam Islam, termasuk didalamnya berbagai keputusan keputusan yang dikeluarkan oleh organisasi kemasyarakatan Islam baik yang berskala Lokal, Nasional, maupun Internasional, hasil hasil penelitian, artikel artikel ilmiah, buku buku (literatur), dokumen dokumen resmi, arsip arsip dan data statistik tentang perkembangan pembiayaan bagi hasil perbankan syariah serta data lain yang diperlukan.

Di dalam penelitian hukum, data sekunder mencakup bahan hukum primer, bahan hukum sekunder dan bahan hukum tertier ${ }^{16}$.

\footnotetext{
${ }^{16}$ Soejono Soekanto dan Sri Mamudji, Penelitian Hukum Normatif Suatu Tinjauan Singkat, Raja Grafindo Persada, Jakarta, 2004. hal 13
} 


\section{Tehnik pengumpulan data}

Data-data yang diperlukan dalam penelitian ini, akan dikumpulkan melalui 3 (tiga) cara yaitu, melalui observasi, wawancara (intervew) dan studi kepustakaan (liabrary research)

\section{Tehnik Analisa Data}

Sesuai dengan metode pendekatan yang digunakan, maka dalam penelitian ini analisis yang digunakan adalah sebagai berikut:

a). Tahap pertama, mendasarkan pada pendekatan doktrinal, analisis dilakukan dengan menggunakan metode analisis kualitatif. Dalam tahap ini terutama akan dilakukan inventarisasi terhadap berbagai norma hukum yang terkait dengan perbankan dan bank syari'ah pada khususnya. Dalam hal ini akan dilakukan pengumpulan terhadap semua asas-asas dan kaidah-kaidah yang terkait dengan permasalahannya, untuk kemudian diorganisir kedalam suatu sistim yang komprehensif, setelah sebelumnya dilakukan koreksi terhadap keseluruhan asas-asas dan kaidah-kaidah yang telah terkumpul tersebut.

b). Tahap kedua yaitu menggunakan analisis kuantitatif dilakukan dengan mendasarkan pada data laporan tahunan perkembangan jumlah pembiayaan yang diimplementasikan oleh bank syariah di Mataram, guna memperoleh gambaran tentang prinsip Profit and Loss Sharing dengan produk musyarakah dan Mudharabah dan berapa Persen (\%) masing masing produk tersebut dilaksanakan dalam praktek Perbankan Syariah.

\section{Hasil Penelitian dan Analisis}

\section{A. Hasil Penelitian}

\section{Akad dalam kegiatan penghimpunan dana di Perbankan Syariah Mataram}

Pada bank konvensional penghimpunan dana dari masyarakat di lakukan dalam bentuk Tabungan, Deposito dan Giro yang lazim di sebut dengan dana pihak ketiga. Di Perbankan Syariah Cabang Mataram penghimpunan dana di masyarakat di lakukan dengan prinsip Wadi'ah dan Mudharabah. Dalam kegiatan penghimpunan dana ini nasabah bertindak sebagai shahibul maal (pemilik dana) dan bank sebagai mudharib (pengelola). 
Wadi'ah adalah titipan dari satu pihak kepada pihak yang lain, baik individu maupun badan hukum yang harus di jaga dan dikembalikan kapan saja si penyimpan menghendakinya. Tujuan dari perjanjian tersebut adalah untuk menjaga keselamatan barang/uang dari kehilangan, kemusnahan, kecurian dan sebagainya ${ }^{17}$. Dari pengertian tersebut maka rukun dari perjanjian wadiah ini adalah:
a. barang/uang yang dititipkan
b. orang yang menitipkan/nasabah
c. orang yang menerima titipan/bank
d. ijab dan qabul

Konsep wadi'ah yang dikembangkan di Perbankan Syariah Mataram adalah giro wadi'ah dan tabungan wadi'ah, Prinsip wadi'ah yang berlaku untuk tabungan wadiah dan giro wadi'ah adalah ${ }^{18}$ :

a. Prinsip wadi'ah yang diterapkan adalah wadi'ah yad adhmanah, yang berarti bank dapat memanfaatkan dan menyelurkan dana yang disimpan serta menjamin bahwa dana tersebut dapat di tarik setiap saat oleh pemilik dana, namun demikian rekening ini tidak boleh mengalami saldo negatif (overdraft).

b. Keuntungan atau kerugian dari penyaluran dana menjadi hak milik atau ditanggung bank, sedangkan pemilik dana tidak memperoleh imbalan atau menanggung kerugian. Manfaat yang diperoleh pemilik dana adalah jaminan keamanan dari simpanannya serta fasilitas giro dan tabungan lainnya. Bank dapat memberikan bonus kepada pemilik dana namun tidak boleh diperjanjikan dimuka.

Giro wadi'ah adalah produk pendanaan bank syariah berupa simpanan dari nasabah dalam bentuk rekening giro untuk keamanan dan kemudahan

\footnotetext{
${ }^{17}$ Wiroso, Penghimpunan Dana dan Distribusi Hasil Usaha Bank Syariah, Grasindo, Jakarta, 2005. Hal 20

${ }^{18}$ Diolah dari Wawancara penulis dengan Bapak Zainul Marketing Officer BMI Cab. Mataram Tanggal 31 Oktober 2007 dan Bapak Muntaha Mahfud Marketing Officer BSM Cab. Mataram, Tanggal 2 Nopember 2007.
} 
pemakaiannya. beberapa fasilitas giro wadi'ah yang diberikan bank, seperti buku cek, bilyet giro, kartu ATM, wesel bank. Produk Giro wadiah seperti: di Bank Syariah Mandiri Cabang Mataram adalah ${ }^{19}$ : Giro BSM Dollar Singapura, Giro BSM, Giro BSM Valas, Giro BSM OURO. Sementara di Bank Muamalat Indonesia Cabang Mataram adalah giro wadiah bank Muamalat dalam mata uang Rupiah maupun Valas, pribadi maupun perusahaan ${ }^{20}$.

Tabungan wadi'ah adalah produk pendanaan bank syariah berupa simpanan dari nasabah dalam bentuk rekening tabungan untuk keamanan dan kemudahan pemakaiannya akan tetapi tidak sefleksibel giro wadi'ah, karena nasabah tidak dapat menarik dananya dengan cek. Adapun syarat syarat dalam pelaksanaan tabungan wadi'ah ini adalah ${ }^{21}$ :

1. penarikan hanya dapat dilakukan dengan mendatangi bank atau ATM,

2. penarikan tidak dapat dilakukan dengan cek, bilyet giro atau surat perintah pembayaran lainnya yang sejenis,

3. bank hanya dapat menyelenggarakan tabungan dalam rupiah,

Di Bank Muamalat Indonesia Cabang Mataram tabungan wadi'ah di kembangkan dengan Tabungan Umat Junior yang merupakan tabungan khusus untuk pelajar ${ }^{22}$. sedangkan Di Bank Syariah Mandiri Cabang Mataram tabungan wadi'ah yang dikembangkan dalam bentuk produk ${ }^{23}$ : Tabungan Simpatik, Tabungan BSM Dollar.

Mudharabah merupakan prinsip bagi hasil dan kerugian ketika nasabah sebagai pemilik modal (shahibul maal) menyerahkan uangnya kepada bank sebagai pengusaha (mudharib) untuk diusahakan. Keuntungan dibagi sesuai

\footnotetext{
${ }^{19}$ Wawancara dengan Bapak Muntaha Mahfud Marketing Officer BSM Cabang Mataram, Tanggal 2 Nopember 2007

${ }^{20}$ Wawancara dengan Bapak Zainul Marketing Officer Bank Muamalat Indonesia Cabang Mataram, Tanggal 31 Oktober 2007

${ }^{21}$ Muntaha Mahfud Op Cit.

${ }^{22}$ Zainul, Op.Cit.

${ }^{23}$ Muntaha Mahfud, Op. Cit.
} 
dengan kesepakatan dan kerugian ditanggung oleh pemilik dana atau nasabah. Penghimpunan dana yang mempergunakan adalah dengan prinsip mudharabah muthlaqah, yaitu shahibul maal tidak memberikan batasan batasan atas dana yang di investasikannya, mudharib diberi wewenag penuh mengelola dana tersebut tanpa terikat waktu, tempat, dan jenis usaha. $^{24}$ Penghimpunan dana Mudharabah ini menggunakan prinsip Tabungan (penarikan dilakukan dengan syarat syarat tertentu dan tidak bisa dengan cek dan alat yang di persamakan dengan itu) dan deposito (penarikan hanya dapat dilakukan pada waktu tertentu sesuai kesepakatan ). Beberapa produk yang termasuk Tabungan Mudharabah adalah Tabungan Haji, Tabungan Investa Cendekia, Tabungan Qurban dan Tabungan dengan Kartu SharE. Sedangkan yang termasuk Produk Deposito adalah deposito Bank syariah Mandiri, Deposito BSM Valas dan Deposito Mudharabah.

\section{2. prinsip Bagi Hasil dan Resiko dalam kegiatan penghimpunan dana di Perbankan Syariah Mataram}

Prinsip bagi hasil dalam penghimpunan dana hanya terdapat dalam prinsip Mudharabah sedangkan dalam prinsip wadiah bank tidak di haruskan melakukan bagi hasil terhadapa nasabah, bank hanya akan memberikan bonus sesuai dengan kerelaan bank dan tidak boleh di perjanjikan sebelumnya. Sedangkan apabila mengalami kerugian akibat dari digunakannya dana oleh bank maka bank akan bertanggungjawab atas kerugian tersebut, sebaliknya apabila bank tidak menggunakan dana nasabah tersebut maka resiko tetap ditanggung nasabah sendiri. Adapun cara perhitungan bagi hasil adalah dengan Revenue Sharing artinya bagi hasil yang dihitung dari total pendapatan pengelolaan dana ${ }^{25}$. Ada beberapa factor yang mempengaruhi besar kecilnya bagi hasil di perbankan syariah yaitu ${ }^{26}$ :

a. besaran kontribusi dana investasi

b. penentuan jenis sumber dana yang di ikutsertakan dalam bagi hasil

${ }^{24}$ Zainul, Wawancara. Tanggal 6 Nopember 2007

${ }^{25}$ Ibid.

${ }^{26}$ Wiroso, Op. Cit. Hal 90. 

c. jenis penyaluran dana dan pendapatan yang terkait
d. penentuan pendapatan yang dibagi hasilkan
e. nisbah yang di sepakati sejak awal

\section{Akad dalam kegiatan pembiayaan di Perbankan Syariah Mataram}

Ada 5 (lima) akad besar dalam kegiatan penyaluran dana di perbankan syariah Mataram yaitu; jual beli, bagi Hasil, sewa, menjaminkan dan akad memberi kepercayaan ${ }^{27}$.

a. akad jual beli, terdiri dari Murabahah, Salam, dan Bai Bitsaman Ajil

Murabahah adalah akad jual beli barang pada harga asal dengan tambahan keuntungan yang disepakati. Kedua belah pihak harus menyepakati harga jual dan jangka waktu pembayaran. Harga jual dicantumkan dalam akad jual beli dan jika telah disepakati tidak dapat berubah selama berlakunya akad. Dalam perbankan, murabahah selalu dilakukan dengan cara pembayaran cicilan. Dalam transaksi ini barang diserahkan segera setelah akad, sementara pembayaran dilakukan secara tangguh/cicilan.

Salam adalah transaksi jual beli dimana barang diperjual belikan belum ada. Oleh karena itu barang diserahkan secara tangguh sementara pembayaran dilakukan secara tunai. Hal ini kebalikan dari akad murabahah tersebut diatas. Bank bertindak sebagai pembeli, sementara nasabah sebagai penjual. Dalam akad Salam kualitas, kuantitas, harga dan waktu penyerahan barang harus ditentukan secara pasti.

Bai Bitsaman Ajil adalah menjual dengan harga asal ditambah dengan margin keuntungan yang telah disepakati dan dibayar secara angsuran. Barang diserahkan kepada pembeli.

b. akad Bagi Hasil, terdiri dari Mudharabah dan Musyarakah

${ }^{27}$ Zainul, Tanggal 22 Nopember 2007 
al-mudharabah adalah akad kerja sama usaha antara dua pihak dimana pihak pertama (shahibul maal) menyediakan seluruh (100\%) modal, sedangkan pihak kedua menjadi pengelola. Keuntungan usaha secara mudharabah dibagi menurut kesepakatan yang dituangkan dalam kontrak, sedangkan apabila rugi ditanggung oleh pemilik modal selama kerugian itu bukan akibat kelalaian pihak pengelola (mudharib). Seandainya kerugian tersebut diakibatkan karena kecurangan atau kelalaian mudharib, maka mudharib harus bertanggung jawab terhadap kerugian tersebut.

al-musyarakah adalah akad kerja sama antara dua pihak atau lebih untuk suatu usaha tertentu dimana masing masing pihak memberikan kontribusi dana dengan kesepakatan bahwa keuntungan dan resiko akan ditanggung bersama sesuai dengan kesepakatan. akad Al Musyarakah ini ada dua bentuk aplikasinya dalam kegiatan perbankan syariah di Mataram yaitu: pertama, pembiayaan proyek dimana nasabah dan bank sama sama menyediakan dana untuk membiayai proyek tersebut. Setelah proyek tersebut selesai nasabah mengembalikan dana tersebut bersama bagi hasil yang telah disepakati untuk bank. dan kedua modal venture yaitu penanaman modal dalam jangka waktu tertentu dan setelah itu bank melakukan divestasi atau menjual bagian sahamnya baik secara singkat atau bertahap.

c. akad sewa, Terdiri dari ijarah

Sewa atau ijarah adalah akad yang di lakukan atas dasar suatu manfaat dengan imbalan jasa. Akad yang di pakai dalam kegiatan perbankan syariah di Mataram adalah ijarah Muntahiya bit Tamlik ${ }^{28}$. ijarah adalah akad sewa yang diakhiri dengan kepemilikan barang ditangan si penyewa. Sistem ijarah Muntahiya bit Tamlik ini mirip dengan sistem leasing dalam kegiatan keuangan konvensional, karena keduanya

${ }^{28}$ Zainul, Op. Cit. 
terdapat pengalihan sesuatu dari satu pihak kepada pihak lainnya atas dasar manfaat ${ }^{29}$.

d. akad menjaminkan, terdiri dari kafalah dan hawalah

Kafalah adalah mengalihkan tanggung jawab seseorang yang di jamin dengan berpegang pada tanggung jawab orang lain sebagai penjamin. Atas jasanya penjamin dapat meminta imbalan tertentu dari orang yang dijamin. Al hawalah adalah pengalihan utang dari orang yang berutang kepada orang lain yang wajib menanggungnya. Dalam kegiatan perbankan syariah di Mataram hawalah ini dilakukan dengan produk seperti factoring atau anjak piutang ${ }^{30}$, dimana para nasabah yang memiliki piutang kepada pihak ketiga memindahkan piutang itu kepada bank, bank lalu membayar piutang tersebut dan bank menagihnya dari pihak ketiga itu.

e. akad memberi kepercayaan, terdiri dari wakalah dan Qardh

Al Wakalah adalah pelimpahan kekuasaan oleh satu pihak (muwakil) kepada pihak lain (wakil) dalam hal-hal yang boleh diwakilkan. Atas jasanya maka penerima kekuasaan dapat meminta imbalan tertentu dari pemberi amanah. Sedangkan akad Qardh adalah akad meminjamkan harta kepada orang lain tanpa mengharapkan imbalan. Dalam praktek perbankan syariah di Mataram akad Qardh tersebut dapat diaplikasikan melalui produk Qardh Haji.

\section{4. sistem Bagi Hasil dan Resiko dalam kegiatan Pembiayaan di Perbankan Syariah Mataram}

Sistem bagi hasil (profit and loss sharing) merupakan karakteristik utama Perbankan Syariah secara umum. Dalam akad yang ditanda tangani nasabah dan bank akan ditentukan nisbah bagi hasil yang akan di peroleh masing masing

${ }^{29}$ Ibid.

${ }^{30}$ Ibid 
pihak dari pendapatan/keuntungan usaha yang di jalankan. Nisbah keuntungan harus dinyatakan dalam bentuk persentase antara kedua belah pihak, bukan dinyatakan dalam nilai nominal rupiah tertentu, karena tidak akan pernah tahu keuntungan pasti dari hasil usaha yang dilakukan. Dari hasil penelitian penulis besarnya bagi hasil di perbankan syariah adalah tergantung kesepakatan antara bank dengan nasabah bukan berdasarkan porsi setoran modal, seperti 55\% untuk bank dan $45 \%$ untuk nasabah, 51\% untuk bank dan 49 untuk nasabah, atau bahkan nasabah lebih besar dari pada bank. Kegiatan bagi hasil di dasarkan pada proyeksi-proyeksi atau asumsi-asumsi yang terjadi berdasarkan kondisi rill di lapangan ${ }^{31}$. Ada beberapa faktor yang mempengaruhi besarnya bagi hasil di perbankan syariah adalah ${ }^{32}$ :
a. referensi tingkat (margin) keuntungan
b. perkiraan tingkat keuntungan bisnis/proyek yang di biayai.

\section{5. kendala operasional yang dihadapi dalam implementasi prinsip Bagi Hasil dan Resiko di Perbankan Syariah Mataram dan solusi mengatasi kendala tersebut.}

Berdasarkan hasil penelitian yang dilakukan oleh peneliti pada Bank Muamalat Indonesia Cabang Mataram dan Bank Syariah Mandiri Cabang Mataram ditemukan beberapa hal yang berkaitan dengan permasalahan yang diangkat dalam penelitian ini. Beberapa factor yang menjadi kendala operasional bank syariah dalam implementasi prinsip Bagi Hasil dan Resiko secara umum dapat dibagi dalam dua factor yaitu factor yang bersifat internal dan factor yang bersifat ekternal ${ }^{33}$.

a. Faktor internal

i. Sumber daya manusia

${ }^{31}$ Zainul, Wawancara Tangga 10 Desember 2007

${ }^{32}$ Adiwarman A. Karim, Bank Islam: Analisis Fiqih dan Keuangan, Grafindo Persada, Jakarta, 2004. Hal. 286.

${ }^{33}$ Zainul, Wawancara Tanggal 28 Desember 2007 

ii. Manajemen
iii. Tehnologi
iv. Jaringan kantor

b. Faktor Eksternal

i. Regulasi pemerintah

ii. Perilaku Masyarakat.

iii. Standar fatwa

iv. Moral hazar nasabah

Ada beberapa solusi dalam menghadapi kendala operasional di perbankan syariah mataram yaitu:

1. mengharapkan peran serta Perguruan Tinggi Negeri dan Swasta dalam mempersiapkan Sumber Daya Manusia yang kompeten dalam keuangan syariah, selama ini belum ada perguruan tinggi di Mataram yang khusus membuka program perbankan syariah. Di Fakultas Hukum Universitas Mataram sudah mulai menggagas dengan membuka mata kuliah khusus ekonomi Islam.

2. melakukan beberapa training terhadap beberapa pegawai/staf perbannkan syariah untuk memperdalam pengetahuan terhadap manajemen ekonomi syariah.

3. memperluas jaringan kantor cabang yang sudah ada sekarang. Menurut Bapak Zainal Maketing Officer BMI Mataram, BMI berencana membuka kantor cabang pembantu di seluruh kabupaten/kota di NTB.

4. melakukan seminar seminar dan pendekatan terhadap Tuan Guru, tokoh masyarakat, birokrat, dan pengusaha untuk mensosialisasikan perbankan syariah dan produk yang ada di perbankan syariah.

5. untuk meminimalkan dan menghapus perilaku menyimpang dari nasabah maka bank syariah menerapkan: 
- bank mengumpulkan lebih banyak informasi yang relevan dengan kinerja nasabah. Melalui informasi itu pihak bank akan dapat menyimpilkan bahwa keadaan riil manakala keadaan riil itu memanng direalisasikan.

- Membuat akad/perjanjian yang memiliki struktur insentif yang dapat mengurangi perilaku usaha yang curang dari nasabah.

- Bank syariah mengadakan monitoring, dan meminta laporan secara berkala kepada nasabah.

\section{B. Analisis}

\section{Akad dalam Kegiatan Penghimpunan dana di Perbankan Syariah Cabang Mataram}

Berdasarkan ketentuan dalam Undang undang no 7 Tahun 1992 tentang perbankan maupun Undang Undang perubahannya, bentuk penghimpunan dana dapat dilakukan melalui penerimaan simpanan dari masyarakat. Simpanan adalah dana yang dipercayakan oleh masyarakat kepada bank berdasarkan akad/perjanjian penyimpanan dalam bentuk giro, tabungan, deposito dan bentuk lainnya yang dipersamakan dengan itu.

Kegiatan penghimpunan dana dan pembiayaan merupakan kegiatan pelayanan jasa perbankan syariah yang utama dari semua kegiatan lembaga keuangan bank syariah. Pelayanan jasa berupa penghimpunan dana dari masyarakat dapat dilakukan dengan prinsip Wadi'ah dan Mudharabah. Di samping mendapatkan dana dari masyarakat Perbankan Syariah juga akan mendapatkan dana dalam bentuk modal yang disetorkan pada saat pendirian bank syariah. Modal adalah dana yang diserahkan oleh pemilik (owner) ${ }^{34}$.

Produk penghimpunan dana dengan akad wadiah ini adalah Giro, dan Tabungan wadiah.

\footnotetext{
${ }^{34}$ M. Syafi'I Antonio, Bank Syariah: dari Teori Ke Praktek, Gema Insani Press. Hal 146
} 
Giro wadiah, Nasabah menitipkan dananya dan setiap saat nasabah berhak mengambilnya dan berhak mendapatkan bonus dari keuntungan pemanfaatan dana giro oleh bank. Besarnya bonus tidak ditetapkan di muka tetapi benar benar merupakan "kebijaksanaan" bank. Giro Wadiah seharusnya merupakan titipan murni, bank tidak mempergunakan untuk investasi dan pembiayaan. Jika kemudian dimodifikasi dengan memberi rekomendasi kepada bank untuk mempergunakannya dan memanfaatkan hasilnya, hal itu tergantung kesepakatan para pihak (kerelaan shahibul maal). Namun pemberian bonus oleh bank sebagaimana praktek saat ini walaupun tidak ditentukan dimuka dalam konteks wadiah belum dapat diterima. Dalam kondisi yang demikian sebenarnya tidak perlu memakai model "wadiah", tapi dengan aqad syirkah mudharabah saja. Dalam kontrak Islam dikenal wadiah yad amanah, merupakan titipan murni, harta yang dititipkan diadministrasikan dalam pembukuan yang terpisah dengan kekayaan bank. Penyimpan tidak bertanggung jawab atas kerusakan atau kehilangan barang yang disimpan yang tidak disebabkan perbuatan atau kesalahan penyimpan.sedangkan dalam tabungan wadiah lebih gampang dari pada giro wadiah karena dapat ditarik dapat ditari memalui ATM.

Akad lain dalam penghimpunan dana adalah Mudharabah secara terminologi Mudharabah adalah pemilik harta menyerahkan harta kepada pihak lain untuk diniagakan keuntungan di bagi dua sesuai dengan kesepakatan dan kerugian hanya dibebankan kepada pemilik benda pihak kedua tidak dibebani kerugian ${ }^{35}$. Definisi tersebut dianggap paling lengkap karena memperhatikan tiga hal, yaitu: pertama, adanya penyerahan benda dari pemilik kepada pihak lain, kedua, adanya ketentuan mengenai pembagian keuntungan yaitu keuntungan di bagi dua dengan presentase sesuai dengan kesepakatan, dan ketiga, adanya pernyataan tentang kerugian. Produk penghimpunan dana dengan akad Mudharabah ini adalah tabungan dan deposito Mudharabah

\footnotetext{
35 Jaih Mubarok, Perkembangan Fatwa Ekonomi Syariah di Indonesia, Pustaka Bani Quraisy, Bandung, 2001 Hal. 51.
} 
Tabungan mudharabah, dana yang disimpan nasabah akan dikelola bank, guna memperoleh keuntungan. Bank sebagai mudarib membagi keuntungan dengan shahib al-mal sesuai dengan nisbah (presentase) yang berlaku. Pembagian biasanya dilakukan tiap bulan berdasarkan saldo yang mengendap. Tabungan mudharabah mengandung unsur ketidakpastian (gharar), karena nasabah sewaktu-waktu dapat menarik dananya dari bank sehingga menimbulkan fluktuasi dana nasabah tersebut yang disimpan di bank. Untuk menghilangkan unsur gharar yang dilarang dalam Islam ini maka dalam Prakteknya bank syariah Mataram menentukan limit waktu penarikan dana nasabah, artinya nasabah tidak bisa menarik dananya sewaktu waktu seperti menggunakan Anjungan Tunai Mandiri (ATM) akan tetapi akan ada kesepakatan tentang penarikan dana.

Deposito investasi mudharabah, simpanan pihak ketiga yang peraturannya hanya dapat dilakukan dalam jangka waktu tertentu (jatuh tempo), dengan mendapatkan imbalan bagi hasil dalam bentuk berbagai pendapatan atas penggunaan dana tersebut. Tabungan haji mudharabah, simpanan pihak ketiga yang penarikannya dilakukan pada saat nasabah akan menunaikan ibadah haji atau pada kondisi-kondisi tertentu sesuai dengan perjanjian nasabah merupakan simpanan dengan memperoleh imbalan bagi hasil (mudharabah). Tabungan qurban, simpanan pihak ketiga yang dihimpun untuk ibadah qurban dengan penarikan dilakukan pada saat nasabah akan melaksanakan ibadah qurban, atau atas kesepakatan antara pihak bank dan nasabah. Juga merupakan simpanan yang akan memperoleh imbalan bagi hasil (mudharabah). Ketiga bentuk terakhir ini, belum diketemukan unsur yang meragukan.

Menurut Gemala Dewi dalam melakukan penghimpunan dana masyarakat bank konvensional dan bank syariah mempunyai perbedaan paradigma yang sangat mendasar yaitu ${ }^{36}$ :

a. Tujuan masyarakat menyerahkan dananya pada bank konvensional dimaksudkan untuk menabung dan mengamankan dananya dari

\footnotetext{
${ }^{36}$ Gemala Dewi, Aspek Aspek Hukum Dalam Perbankan dan Perasuransian Syariah di Indonesia, Kencana, Jakarta, 2006. Hal 108.
} 
kemungkinan hal hal yang tidak diharapkan disamping mengharapkan bunga dari dana yang disimpan tersebut.

b. Tujuan masyarakat menyalurkan dananya pada bank syariah adalah untuk di investasikan dalam berbagai pembiayaan. Apabila memperoleh laba akan dibagi sesuai nisbah bagi hasil, sedangkan apabila menderita kerugian maka masyarakat ikut menanggung kerugian tersebut.

Menurut Deputi Bank Indonesia Bagian Perbankan Syariah Siti Chalimah Fadrijah Selama ini nasabah bank syariah ada dua macam yaitu nasabah rasional dan nasabah emosional/loyalis ${ }^{37}$. Nasabah rasional adalah yang bisa membaca peluang bisnis, apabila dalam keadaan menguntungkan akan menggunakan jasa Perbankan Syariah dan apabila keadaan tidak menguntungkan lebih memilih bank konvensional yang memberikan tingkat bunga yang pasti. Sedangkan nasabah emosional/loyalis adalah nasabah yang menggunakan jasa Perbankan Syariah dikarenakan tuntutan agama khususnya syariat Islam yang mengharamkan bunga bank.

Secara umum antara nasabah dengan bank melakukan hubungan hukum yaitu melakukan perjanjian atau akad dimana nasabah menyerahkan uangnya untuk dipergunakan dan dikelola oleh bank. Perjanjian menurut Yan Pramadya Puspa adalah suatu perbuatan dimana seseorang atau lebih mengikatkan dirinya terhadap seseorang lain atau lebih ${ }^{38}$.

Perbuatan hukum ini dapat di lakukan oleh orang perorang maupun dilakukan oleh kelompok orang dan atau korporasi. Perbuatan hukum yang dilakukan oleh korporasi adalah korporasi yang berbadan hukum dimana yang mewaikili korporasi tersebut adalah direksinya.

Perjanjian yang menimbulkan akibat hukum hanya dapat dilakukan oleh oleh orang yang cukup umur atau cakap dan tidak berada dibawah pengampuan. Untuk mengukur kedewasaan seseorang dalam Islam ditentukan aqil balik yakni pernah mimpi basah, sementara dalam hukum positif nasional

\footnotetext{
${ }^{37}$ Siti Chalimah Fadrijah, Gatra Edisi Khusus, 24 Oktober 2007

${ }^{38}$ Chairuman Pasaribu dan Suhrawardi K. Lubis, Hukum Perjanjian dalam Islam, Sinar Grafika, Jakarta, 1996, Hal. 1
} 
yakni dalam Undang undang perkawinan seseorang dikatakan dewasa apabila telah berumur 19 tahun bagi laki laki dan 16 tahun bagi perempuan dan atau sudah menikah. Sementara dalam perjanjian tabungan diperbankan contohnya Tabungan Simpatik di Bank Syariah Mandiri Mataram dimana tabungan ini di peruntukan bagi anak anak dengan tujuan untuk mempersiapkan masa depannya. Anak di bawah umur tidak bisa melakukan perbuatan hukum sesuai dengan pasal $1330 \mathrm{KUH}$ Perdata. Untuk kasus ini anak tersebut dapat mewakilkan kepada orang tua atau walinya untuk melakukan perbuatan hukum atas nama anak tersebut. Begitupun juga seorang Istri tidak boleh melakukan tindakan hukum kecuali atas ijin suaminya.

\section{Prinsip Bagi Hasil dan risiko dalam Penghimpunan dana di Perbankan Syariah Cabang Mataram}

Bagi hasil dalam penghimpunan dana pada dasarnya hanya terdapat dalam akad Mudharabah sedangkan pada akad Wadi'ah tidak terdapat bagi hasil hanya berupa bonus yang di berikan secara sukarela pada oleh bank tanpa di perjanjikan sebelumnya. Pada saat dimana keadaan persaingan usaha yang sangat ketat dan kempetitif bagi perbankan seperti sekarang ini bonus sepertinya merupakan sesuatu yang mutlak hal ini dimaksudkan untuk merangsang nasabah agar menggunakan akad wadi'ah ini. Menurut Adiwarman A. Karim bahwa Perbankan Syariah di Arab kadang kadang memberikan bonus wadiah kepada nasabahnya dalam bentuk mobil ${ }^{39}$. Bonus ini berbeda dengan hadiah seperti yang sering dilakukan oleh perbankan konvensional untuk merangsang nasabah agar mau menabung di bank tersebut.

Dalam konsideran fatwa Dewan Syariah Nasional Majelis Ulama Indonesia No 15/DSN MUI/IX/2000 dinyatakan bahwa dalam bagi hasil terdapat dua prinsip yaitu, pertama, prinsip bagi untung (profit sharing), yaitu bagi hasil yang di hitung dari pendapatan setelah di kurangi biaya

\footnotetext{
${ }^{39}$ Adiwarman A. Karim. Gatra, Ibid.
} 
pengelolaan, dan kedua, prinsip bagi hasil (revenue sharing) adalah bagi hasil yang dihitung dari total pendapatan pengelolaan dana.

\section{Akad Dalam Kegiatan Pembiayaan di Perbankan Syariah Cabang Mataram}

Kegiatan bank setelah menghimpun dana dari masyarakat dalam bentuk berbagai simpanan adalah menyalurkan kembali dana tersebut kepada masyarakat yang memerlukannya. Secara umum penyaluran dana dalam perbankan yang menggunakan system konvensional adalah pemberian kredit. Sedangkan dalam perbankan syariah penyaluran dana dilakukan dengan pembiayaan. Akad pembiayaan dalam perbankan syariah adalah seperti: akad jual beli (murabahah, salam, bai bitsaman ajil), akad bagi hasil (mudharabah dan Musyarakah), akad sewa (ijarah), akad menjaminkan (kafalah dan hawalah), dan akad memberi kepercayaan (wakalah).

Secara ringkas dapat dikatan bahwa keempat mazhab membolehkan pembebanan biaya langsung yang harus di bayarkan kepada pihak ketiga. Keempat mazhab sepakat tidak membolehkan pembebanan biaya langsung yang berkaitan dengan pekerjaan yang memang semestinya dilakukan oleh penjual maupun biaya langsung yang berkaitan dengan hal hal yang berguna. Keempat mazhab juga membolehkan juga membolehkan pembebanan biaya tidak langsung yang dibayarkan kepada pihak ketiga dan pekerjaan itu harus dilakukan oleh pihak ketiga. Bila pekerjaan itu harus dilakukan oleh si penjual, mazhab Maliki tidak membolehkan pembebanannya, sedangkan ketiga mazhab lainnya membolehkannya. Keempat mazhab sepakat tidak membolehkan pembebanan biaya tidak langsung bila tidak menambah nilai barang atau tidak berkaitan dengan hal hal yang berguna.

Bagi hasil merupakan pembagian keuntungan yang diperoleh dari suatu usaha yang halal berdasarkan keadilan. Keadilan dalam konteks ini adalah pemodal berhak mendapatkan imbalan yang sepadan dengan risiko 
dan usaha yang dibutuhkan. Dan nasabah mendapatkan porsi bagi hasil dari pekerjaan yang dilakukannya sehingga mengasilkan keuntungan. Pembagian keuntungan yang sah dan dapat diterima menjadi fondasi pengembangan dan implementasi perbankan Syariah. Dalam Islam pemilik modal dapat secara sah mendapatkan bagian dari keuntungan yang didapat oleh pelaksanaan usaha. Sistem bagi hasil di perbolehkan dalam Islam karena yang ditetapkan sebelumnya adalah rasio bagi hasil, bukan tingkat keuntungan, seperti yang berlaku dalam sistem bunga. Keuntungan yang di bagi hasilkan harus dibagi secara proporsional antara pemodal (shahibul maal) dan mudharib. Dengan demikian semua pengeluaran rutin yang berkaitan dengan bisnis, bukan untuk kepentingan pribadi mudharib dapat dimasukkan dalam biaya operasional. Keuntungan bersih harus dibagi antara shahibul maal dan mudharib sesuai dengan proporsi yang disepakati sebelumnya dan secara eksplisit di sebutkan dalam perjanjian awal.

\section{Prinsip Bagi Hasil dan Risiko dalam Pembiayaan di Perbankan Syariah Cabang Mataram}

Dengan melarang riba, islam berusaha membangun sebuah masyarakat berdasarkan kejujuran dan keadilan. Dalam lemabaga keuangan konvensional Seorang kreditor akan mendapatkan keuntungan dari debitur, tanpa memedulikan hasil usaha dari debitur. Akan lebih adil jika kedua pihak kreditor dan debitor sama sama menanggung keuntungan maupun kerugian. Hal inilah yang sedang yang diterapkan dalam ekonomi Islam dimana kedua belah pihak sama sama menanggung keuntungan maupun kerugian asalkan kerugian tersebut bukan diakibatkan kelalaian dan kesengajaan debitor.

Di sini di butuhkan kepercayaan dan kejujuran dari masing masing

pihak. Keadilan dalam kontek ekonomi Islam adalah memiliki dua dimensi yaitu: pemodal berhak mendapatkan imbalan yang sepadan 
dengan risiko dan debitor mendapatkan modal usaha yang butuhkan dan bagi hasil dengan demikian di tentukan oleh keuntungan usahanya ${ }^{40}$. Pembagian keuntungan yang sah dan dapat diterima menjadi fondasi pengembangan dan implementasi perbankan Islam. Dalam Islam pemilik modal dapat secara sah mendapatkan bagian dari keuntungan yang didapat oleh pelaksanaan usaha. Sistem bagi hasil di bolehkan dalam Islam karena yang ditetapkan sebelumnya adalah rasio bagi hasil, bukan tingkat keuntungan seperti yang berlaku dalam sistem bunga. Menurut hukum ekonomi Islam, kemitraan dan semua organisasi bisnis lainnya didirikan dengan satu tujuan yaitu pembagian keuntungan dengan partisipasi bersama.

Dalam sistem perbankan syariah menggunakan bagi hasil dan tidak menggunakan bunga, hal ini disebabkan ${ }^{41}$ :

1. doktrin kerja sama dalam ekonomi Islam dapat menciptakan kerja produktif sehari hari dari masyarakat (QS. Al Baqarah ayat 190)

2. meningkatkan kesejahteraan dan mencegah kesengsaraan sosial (QS. Ali Imran ayat 103, Al Maidah ayat 3 dan Attaubah ayat 71 dan 105),

3. mencegah penindasan ekonomi dan distribusi kekayaan yang tidak merata (QS. Al Haaqqah ayat 25-37, Al Fajr ayat 17-20 dan Al Maa'uun ayat 1-7),

4. melindungi kepentingan ekonomi lemah (QS. An Nisa ayat 5-10, 7476 dan Al Fajr ayat 17-26),

5. membangun organisasi yang berprinsip syarikat, sehingga terjadi proses yang kuat membantu yang lemah (QS. Az Zukhruf ayat 32),

6. pembagian kerja atau spesialisasi berdasarkan saling ketergantungan serta pertukaran barang dan jasa karena tidak mungkin berdiri sendiri (QS. Al Lail ayat 8-10, dan Al'Alaq ayat 6).

\footnotetext{
${ }^{40}$ Mervyn K. Lewis dan Latifa M. Algaoud, Bank Syariah, Serambi, 2007 Hal 58.

${ }^{41}$ Muhammad, Op. Cit. Hal 24
} 
Dalam penerapan sistem bagi hasil ini tidak selamanya perjanjian itu dilaksanakan sesuai dengan apa yang di sepakati dalam kontrak atau akad. Sering terjadi bahwa nasabah atau bank tidak melaksanakan apa yang di perjanjikan atau wanprestasi atau ingkar janji.

Menurut Subekti Wanprestasi dapat berupa empat macam yaitu ${ }^{42}$ :

1. tidak melakukan apa yang disanggupi akan dilakukannya;

2. melaksanakan apa yang diperjanjikan, tetapi tidak sebagaimana diperjanjikan;

3. melakukan apa yang di janjikanya tetapi terlambat;

4. melakukan sesuatu yang menurut perjanjian tidak boleh dilakukannya.

Dalam Islam pembolehan untuk membatalkan perjanjian oleh salah satu pihak apabila yang lainnya menyimpang dari apa yang di perjanjikan adalah didasarkan kepada ketentuan Al Qur'an surah At Taubah ayat 7:

“maka selama mereka berlaku jujur (lurus) terhadapmu, hendaklah kamu berlaku lurus pula terhadap mereka. Sesungguhnya Allah menyukai orang orang yang bertakwa"

Dari ketentuan ayat diatas khususnya dalam kalimat "selama mereka berlaku lurus terhadapmu hendaklah kamu berlaku lurus pula terhadap mereka”, dalam hal ini terkandung pengertian bahwa apabila salah satu pihak tidak berlaku lurus, maka pihak yang lain boleh membatalkan perjanjian yang telah disepakati. Ketentuan lain mengenai pembatalan perjanjian ini adalah dalam Surah At Taubah ayat 12dan 13:

Ayat 12, artinya bahwa "jika mereka merusak janji, sesudah mereka berjanji, dan mereka mencerca agamamu, maka perangilah pemimpin orang orang yang ingkar tersebut (kafir), karena sesungguhnya mereka itu orang orang yang tidak dapat dipegang janjinya, agar mereka berhenti”.

Sedangkan ayat 13, artinya "mengapakan kamu tidak memerangi orang orang yang merusak janji, padahal mereka telah keras

\footnotetext{
${ }^{42}$ Subekti, Hukum Perjanjian. Hal. 45
} 
kemauannya untuk mengusir Rasul dan merekalah yang pertama kali memulai memerangimu. Apakah kamu takut kepada mereka?, padahal Allah yang lebih berhak untuk kamu takuti jika kamu benar benar orang orang yang beriman".

Prosedur pembatalan perjanjian dilakukan, terlebih dahulu kepada pihak yang tersangkut dalam perjanjian tersebut diberitahu, bahwa perjanjian atau kesepakatan yang telah diikat akan di hentikan (dibatalkan), hal ini tentunya harus juga diberitahukan alasannya. Setelah diberitahu maka diberikan waktu yang dimaksudkan sebagai persiapan agar pihak yang tersangkut dalam perjanjian bersiap siap menghadapi risiko pembatalan. Adapun dasar hukum ketentuan ini adalah Surah Al Anfal ayat 58: "dan jika kamu khawatir akan (terjadinya) ada penghianatan dari suatu golongan, maka kembalikanlah perjanjian itu kepada mereka dengan jujur. Sesungguhnya Allah tidak menyukai orang orang yang berkhianat".

\section{Solusi dan strategi untuk Mengembangkan Syariah Cabang Mataram}

Pengembangan bank syariah kedepannya bukan lagi terfokus pada sosialisasi terhadap keberadaan perbankan syariah. Dari hasil survei yang dilakukan oleh bank indonesia dan penelitian akademik lainnya menyebutkan bahwa hampir semua lapisan masyarakat telah mengetahui eksistensi bank syariah sebagai perbankan yang berdasarkan hukum syariah. Hal yang perlu dilakukan kedepannya adalah menjelaskan nilai tambah yang ditawarkan oleh perbankan syariah sehingga mengundang minat masyarakat karena bagaimanapun juga tujuan utama menggunakan perbankan syariah di samping untuk tujuan akhirat dengan tidak memakan sesuatu yang riba juga masyarakat menginginkan sesuatu yang lebih baik dan menguntungkan. Hal ini dilakukan kepada calon nasabah (debitor) namun juga para pengusaha (peminjam dana) dan publik secara keseluruhan.

Syarat sukses penerapan pembiayaan Mudharabah dan Musyarakah dapat dilakukan baik melalui rekrutmen Sumber Daya Manusia yang kompeten maupun 
kerja sama dengan lembaga swasta untuk menilai kelayakan dan progres pembiayaan yang tengah berjalan. Sistem informasi debitor, sistem informasi kredit dan potensi kredit yang telah dikembangkan Bank Indonesia dapat menjadi salah satu faktor pendukung lainnya.

Kendala lainnya yang membuat bank syariah kurang memahami nasabah adalah kekhawatiran gagal bayar (default) dan kurangnya fariasi produk, promosi produk, dan fleksibilitas produk. Masalah default dapat diatasi asalkan terdapat kejujuran, kepercayaan, dan good will dari pelaku keuangan syariah. Demikian pula untuk pembiayaan yang berskala besar dengan risiko tinggi, hal ini memerlukan kterlibatan pemerintah selain bank syariah sebagai intermediator yang menerbitkan sukuk (obligasi syariah). Ketika landasan hukum sukuk diterbitkan diharapkan high risk financing bukan lagi menjadi kendala berarti. Bahkan potensi dana dana simpanan syariah yang ditanamkan dalam bentuk sukuk dapat disalurkan untuk membiayai proyek proyek pembangunan pemerintah yang berjangka panjang ${ }^{43}$.

Menurut Deputi Bank Indonesia Siti Chalimah Fadrijah ada beberapa hal yang perlu di lakukan dalam mengembangkan perbankan syariah yaitu ${ }^{44}$ :

a. Sumber Daya Manusia dan Kesiapan pimpinan bank,

b. Komitmen para pihak untuk menambah kapasitas modal,

c. Infrastruktur mulai dari keberadaan outlet sampai sistem informasi dan teknologi

d. Mendorong disersivikasi produk, karena tidak mungkin jika masing masing bank melakukan penelitian untuk menghasilkan suatu produk baru. Maka alternatifnya adalah menginovasi satu produk yang menjadi unggulan dan selanjutnya di share bersama sama.

Dalam rangka pemulihan ekonomi Indonesia diburuhkan peran intermediasi dari perbankan sebagai penggerak perekonomian nasional. Peran ini

\footnotetext{
${ }^{43}$ Rifki Ismail, Ganjalan Bank Syariah. Opini Republika, Senin 10 Desember 2007

${ }^{44}$ Gatra Edisi khusus 2007 No. 48 Tahun XIII 11-24 Oktober 2007 . Hal 12.
} 
hanya dilaksanakan jika perbankan beroperasi dalam kondisi yang sehat dan dalam lingkungan bisnis yang kondusif. Ada beberapa strategi dalam mengembangkan perbankan syariah yaitu:

a. Harus dipahami bahwa kondisi perekonomian Indonesia adalah ekonomi kerakyatan oleh akrena itu sudah saatnya perbankan syariah mulai melirik untuk menjalin kerja sama dengan Usaha kecil dan Menengah yang ada di tengah tengah masyarakat,

b. Agar menyentuh lapisan terbawah dari masyarakat sekaligus upaya sosialisai dan edukasi, bank syariah bisa melakukan pelatihan dan pendidikan bagi masyarakat dalam rangka mencetak enterpreneur enterpreneur yang andal dan kompetetif. Untuk merealisasikan strategi ini bank syariah dapat menjalin kerja sama dengan Perguruan Tinggi atau lembaga yang berkompeten dalam bidang pendidikan dan pelatihan kewirausahaan.

c. Mengoptimalkan Qardhul Hasan yang bisa diambil dari dana zakat, infak dan shadaqah. Sudah saatnya potensi keuangan yang tersimpan tidak lagi menjadi dana konsumtif tetapi poensi besar ini dijadikan modal dan dikelola menjadi dana yang produktif.

d. Perbankan syariah juga dituntut untuk membangun kerja sama yang solid dalam pembiayaan dengan usaha kecil terutama dengan Bank Perkreditan Rakyat Syariah dan Baitul Maal wa Tanwil, kedua lembaga inilah yang banyak bersentuhan langsung dengan rakyat kecil.

\section{Kesimpulan dan Saran}

\section{1. kesimpulan}

Bertolak dari perumusan masalah dan uraian hasil penelitian dan analisis yang dikemukakan pada bab bab sebelumnya, maka dalam penulisan tesis ini dapat diambil beberapa kesimpulan, sebagaui berikut:

1. Pelaksanaan penghimpunan dana dengan menggunakan prinsip bagi hasil di Perbankan Syariah Mataram dilakukan dengan menggunakan prinsip 
Wadi,ah dan Mudharabah. Prinsip wadiah menggunakan akad giro wadiah dengan menggunakan produk seperti: Giro BSM Dollar Singapura, Giro BSM, Giro BSM Valas, Giro BSM OURO, giro wadiah bank Muamalat dalam mata uang Rupiah maupun Valas, pribadi maupun perusahaan, dan Tabungan Wadiah menggunakan produk seperti: Tabungan Umat Junior yang merupakan tabungan khusus untuk pelajar, Tabungan Simpatik, Tabungan BSM Dollar. Sedangkan prinsip mudharabah menggunakan akad tabungan Mudharabah dengan menggunakan produk seperti: Tabungan Mudharabah adalah Tabungan Haji, Tabungan Investa Cendekia, Tabungan Qurban dan Tabungan dengan Kartu SharE dan deposito mudharabah menggunakan produk seperti: deposito Bank syariah Mandiri, Deposito BSM Valas dan Deposito Mudharabah. Pada perhitungan bagi hasil hanya pada prinsip Mudharabah sedangkan pada prinsip wadiah hanya berupa bonus yang diberikan atas kerelaan bank. Pola perhitungan bagi hasilnya adalah dengan menggunakan prinsip revenue sharing artinya bagi hasil yang dihitung dari total pendapatan penegelolaan dana dan besarnya porsi bagi hasil tergantung dari kesepakatan awal.

2. Pelaksanaan penyaluran dana dalam kegiatan pembiayaan di Perbankan Syariah Mataram menggunakan beberapa akad seperti akad Jual beli, akad bagi hasil, akad sewa, akad menjaminkan dan akad memberi kepercayaan. Akad bagi hasil menggunakan mudharabah dan musyarakah. Dalam implementasi pembiayaan dengan prinsip ini masih rendah dibandingkan dengan prinsip pembiayaan lainnya seperti murabahah, hal ini disebabkan beberapa Faktor seperti kesulitan mencari dan mendapatkan nasabah yang jujur, berkarakter baik dan berintegrasi tinggi, tingginya resiko yang harus ditanggung bank, masih kurangnyatehnologi pembiayaan bagi hasil, masih kurangnya SDM di Perbankan Syariah Mataram yang paham masalah pembiayaan bagi hasil, sikap masyarakat yang masih menganggap produk Perbankan Syariah sama saja dengan bank konvensional dan tidak adanya standar moral dalam kegiatan pembiayaan Bagi Hasil. 
3. Ada beberap kendala operasional yang di hadapi oleh Perbankan Syariah Mataram dalam implementasi pembiayaan Bagi Hasil seperti kendala Sumber Daya Manusia Insani, manajemen Perbankan Syariah, Jaringan Kantor yang masih terbatas, dan masih lemahnya regulasi pemerintah terhadap Perbankan Syariah.

\section{2. saran}

Menilik pada hasil penelitian dan analisa dan kesimpulan diatas, maka dalam tesis ini disarankan sebagai berikut:

1. Untuk lebih banyak menarik minat masyarakat dalam menggunakan jasa Perbankan Syariah bukan Cuma melakukan sosialisai akan tetapi bank syariah langsung melakukan jemput bola artinya bank syariah langsung turun ke lokasi lokasi masyarakat, lebih banyak mengeluarkan produk yang lebih efektif dan dapat menjangkau masyarakat bawah seperti Shar'e di Bank Muamalat Indonesia, di samping itu lebih banyak melakukan pendekatan terhadap Tuan Guru dan tokoh masyarakat.

2. Harus dipahami bahwa kondisi perekonomian Indonesia adalah ekonomi kerakyatan oleh karena itu Perbankan Syariah harus dapat lebih mengoptimalkan perkonomian yang berbasis kemasyarakatan artinya memberikan pembiayaan bagi hasil untuk kegiatan kegiatan ekonomi riil masyarakat seperi industri rumah tangga dan kegiatan kegiatan pertanian seperti di lombok adalah pertanian tembakau yang lebih banyak di manfaatkan oleh tengkulak tengkulak.

3. Untuk mengatasi kendala operasional seperti masih kurangnya Sumber Daya Manusia Insani Perbankan Syariah dapat melakukan kerja sama dengan sekolah sekolah dan perguruan Tinggi yang ada untuk dapat

menciptakan kurikulum yang berbasis eknomi Islam. Disamping itu melakukan seleksi secara ketat terhadap pembiayaan bagi hasil yang memiliki resiko kerugian yang tinggi dan memonitringnya setiap saat. 


\section{DAFTAR PUSTAKA}

$\underline{\text { Buku buku }}$

A. Karim Adiwarman, 2001, Ekonomi Islam Suatu Kajian Kontemporer, Gema Insani Press, Jakarta

A. Ghufron Mas'adi, 2002, Fiqih Muamalah Kontekstual, Cet. I, Raja Grafindo Persada, Jakarta,

Arifin, Hamid M. 2007, Hukum ekonomi Islam (Ekonomi Syariah) Di Indonesia Aplikasi dan Prospektifnya, Ghalia Indonesia, Bogor.

Ascarya, 2007. Akad dan Produk Bank Syariah, Raja Grafindo Persada. Jakarta.

Ashshofa, Burhan, 2004. Metode Penelitian Hukum, Rineka Cipta, Jakarta.

Chapra, Umer, 1999, Islam And The Economic Challenge, dalam bahasa Indonesia Islam Dan Tantangan Ekonomi Islamisasi Ekonomi Kontemporer, Risalah Gusti, Surabaya

Darus Badruzzaman Mariam, 1998 Perjanjian Kredit Bank, Citra Aditya Bakti, Bandung,

Dewi, Gemala, Wirdyaningsih, Yeni Salma Barlinti, 2005, Hukum Perikatan Islam di Indonesia, Kencana dan Badan Penerbit FH UI, Jakarta.

Dewi, Gemala, 2006. Aspek Aspek Hukum dalam Perbankan dan Perasuransian Syariah di Indonesia, Kencana, Jakarta.

Djumhana, Muhammad, 1996, Hukum Perbankan di Indonesia, PT. Citra Aditya Bakti, Bandung.

Djazuli, A, 2002, Lembaga Lembaga Prekonomian Umat (Sebuah Pengenalan), RajaGrafindo Persada, Jakarta.

Faisal, Sanafiah, 1990, Penelitian Kualitatif : Dasar-Dasar Dan Aplikasi, Yayasan 3. A, Malang.

Fauroni, Lukman, 2006. Arah dan Strategi Ekonomi Islam, Magistra Insani Press, Yogyakarta.

H. Kara, Muslim, 2005, Bank Syariah di Indonesia Analisis Kebijakan Pemerintah Indonesia Tentang Perbankan Syariah, UII Press, Yogyakarta,

Hilman, Imam dkk, 2003, Perbankan Syariah Masa Depan, Senayan Abadi Publishing, Jakarta

Ibrahim, Johannes dan Lindawaty Sewu, 2004, Hukum Bisnis Dalam Persepsi Manusia Modern, Refika Aditama, Bandung.

Ilmi, SM Makhalul, 2002. Teori dan Praktek Lembaga Keuangan Mikro Keuangan Syariah Beberapa Permasalahan dan Alternatif Solusi, UII Press, Yogyakarta.

K. Lewis Mervyn, Latifa M. Algaoud, 2007, Perbankan Syariah Prinsip, Praktek, dan Prospek, Serambi, Jakarta. 
Lubis, Suhrawardi, K, 1999, Hukum Ekonomi Islam, Sinar Grafika, Jakarta.

M. Zeitling, Irving, Penerjemah Ansori dan Johanda, Memahami Kembali Sosiologi, Kritik Terhadap Teori Sosiologi Kontemporer, Gajah Mada University Press, Yogyakarta.

M. Saefuddin A, 1987, Ekonomi dan Masyarakat Dalam Perspektif Islam, Rajawali Press, Jakarta,

Moleong, Lexy, J, 2000, Metodologi Penelitian Kualitatif, PT. Remadja Rosdakarya, Bandung.

Mubarok, Jaih, 2004, Perkembangan Fatwa Ekonomi Syariah di Indonesia, Pustaka Bani Quraisy. Bandung.

Muhadjir, Noeng, 1998, Metodologi Penelitian Kualitatif Edisi III, Pendekatan Positivistik, Rasionalistik, Phenomenologik, Realisme-metaphisik, Telaah Studi Teks Dan Penelitian Agama, PT. Bayu Indra Grafika, Yogyakarta.

Muhammad, 2000, Sistem dan Prosedur Operasional Bank Syariah, UII Press, Yogyakarta

, 2000, Lembaga-Lembaga Keuangan Umat Kontemporer, UII Press, Yogyakarta. , 2001, Tehnik dan Perhitungan Bagi Hasil Bank Syariah, UII Press, Yogyakarta , ed, 2004, Bank Syariah Analisis Kekuatan, Kelemahan, Peluang dan Ancaman, Ekonisia Yogyakarta.

Muhammad, Abdulkadir, 1992, Perjanjian Baku dalam Praktek Perusahaan Perdagangan, Citra Aditya Bakti, Bandung.

Nasution, S, 1998, Metodologi Penelitian Naturalistik Kualitatif, Tarsito, Bandung.

P. Simongkir, O. 1983, Etika dan Moral Perbankan, Ind Dhill Co, Jakarta.

Perwataatmadja, Karnaen dan M. Syafi'i Antonio, 1999. Apa dan Bagaimana Bank Syariah, PT. Dana Bhakti Prima Yasa, Yogyakarta.

Pasaribu, Chairuman, dan Suharwadi K. Lubis, 1996. Hukum Perjanjian Dalam Islam, Sinar Grafika. Jakarta.

Poerwadarminta W.J.S, 1996 Kamus Besar Bahasa Indonesia, Jakarta,

Patrik, Purwahid, 1994, Dasar dasar Hukum Perikatan (Perikatan yang lahir dari Perjanjian dan dari Undang Undang), Mandar Maju, Bandung,

Qardhawi, Yusuf, 1997, Membumikan Syariat Islam, Dunia Ilmu, Surabaya. , 1990, Bank Tanpa Bunga, Usamah Press, Jakarta , 1995, Norma dan Etika Ekonomi Islam, Gema Insani Press, Jakarta ,2004. Konsep Islam Solusi Utama Bagi Umat, Senayan Abadi Publishing, Jakarta. 
Rahardjo, Satjipto. 1977. Pemanfaatan Ilmu Ilmu Sosial Bagi Pengembangan Ilmu Hukum. Alumni, Bandung , 1982, Ilmu Hukum. Alumni, Bandung. , 1985, Beberapa Pemikiran Tentang Ancangan Antar Disiplin Dalam Pembianaan Hukum Nasional, Sinar Baru, Bandung.

Rahman Hasanudin, 1995, Aspek Aspek Hukum Pemberian Kredit Perbankan di Indonesia, Citra Aditya Bakti, Bandung,

Redjeki Hartono, Sri, 2007, Hukum Ekonomi Indonesia, Bayumedia Publishing, Malang.

Remy Syahdeini, Sutan, 1999, Perbankan Islam Dan Kedudukannya Dalam Tata Hukum Perbankan Indonesia, Pustaka Utama Grafiti, Jakarta.

Ritzer, George, 1992, Disadur dari Judul Asli : Sociology A Multiple Paradigm Science Oleh Alimandan, Sosiologi Ilmu Pengetahuan Berparadigma Ganda, Rajawali, Press, Jakarta.

Saeed, Abdullah, 2004, Menyoal Bank Syari'ah Kritik Atas Interpretasi Bunga Bank Kaum Neo-Revivalis, Paramadina, Jakarta.

Safi'i Antonio, Muhammad, 1420 H/1999 M, Bank Syari'ah Bagi Bankir dan Praktisi Keuangan, Kerjasama Bank Indonesia dan Tazkia Institut, Jakarta.

, 1420 H/1999 M, Bank Syari'ah Suatu Pengenalan Umum, Kerjasama Bank Indonesia dan Tazkia Institut, Jakarta.

Setiawan, 1994, Pokok Pokok Hukum Perikatan, Bian Cipta, Bandung,

Siddiqi, M. Nejatullah, 1996, Pathnership and Profit Sharing In Islamic Law, diterjemahkan oleh, Mumtihani, Fahkriyah kedalam edisi Bahasa Indonesia, Kemitraan dan Bagi Hasil Dalam Hukum Islam, PT. Dana Bakti Prima Yasa, Yogyakarta.

Soehartono, Irawan, 1999, Metodologi Penelitian Sosial, Suatu Teknik Penelitan Bidang Kesejahteraan Sosial Lainnya, PT. Remadja Rosdakarya, Bandung.

Soekanto, Soejono, 2005. Pengantar Penelitian Hukum, UI Press, Jakarta.

Subekti, 1991, Hukum Perjanjian, Intermasa, Jakarta,.

1991, Jaminan jaminan untuk Pemberian Kredit Menurut Hukum Indonesia, Citra Aditya Bakti, Bandung,

Suhendi, Hendi, 2002, Fiqh Muamalah, PT. RajaGrafindo Persada, Jakarta.

Sumadiningrat, Gunawan, 1999, Sistem Ekonomi Pancasila dalam Perspektif, Impac Wahana Cipta, Jakarta.

Sumantoro, 1986, Hukum ekonomi, UI Press, Jakarta.

Suyanto, Thomas, dkk. 1991, Kelembagaan Perbankan, STIE Perbanas dan Gramedia, Jakarta

Umar, Musni, 2004, Al Qur'an, Demokrasi Politik, dan Ekonomi, Insed, Jakarta. 
Usman, Rachnadi, 2002. Aspek Aspek Hukum Perbankan Islam Di Indonesia, Citra Aditya Bakti, Bandung.

Wibowo, Edy, dan Untung Hendy Widodo, 2005. Mengapa Memilih Bank Syariah?, Ghalia Indonesia, Bogor.

Wiroso, 2005, Penghimpunan Dana dan Distribusi Hasil Usaha Bank Syariah, Grasindo, Jakarta,

$\underline{\text { Majalah Majalah }}$

Gatra edisi 24 Oktober 2007

Kompas 11 Februari 2008

Republika

Peraturan Perundang-undangan

Undang-Undang Nomor 3 Tahun 2004 tentang Bank Indonesia (Lembaran Negara Tahun 2004 Nomor 7);

Undang-Undang Nomor 10 Tahun 1998 tentang Perbankan (Lembaran Negara Republik Indonesia Tahun 1998 Nomor 182);

Peraturan Bank Indonesia Nomor: 8/7/PBI/2006 Tentang Perubahan Atas Peraturan Bank Indonesia Nomor 7/13/PBI/2005 Tentang Kewajiban Penyediaan Modal Minimum Bank Umum Berdasarkan Prinsip Syariah

Peraturan Bank Indonesia Nomor 6/24/PBI/2004 tanggal 14 Oktober 2004 tentang Bank Umum yang Melaksanakan Kegiatan Usaha Berdasarkan Prinsip Syariah

Peraturan Bank Indonesia Nomor: 5/ 7 /PBI/2003 Tentang Kualitas Aktiva Produktif Bagi Bank Syariah

Peraturan Bank Indonesia Nomor : 4/ 1/PBI/2002 Tentang Perubahan Kegiatan Usaha Bank Umum Konvensional Menjadi Bank Umum Berdasarkan Prinsip Syariah Dan Pembukaan Kantor Bank Berdasarkan Prinsip Syariah Oleh Bank Umum Konvensional

Surat Keputusan Direksi Bank Indonesia, Nomor 32/33/Kep/Dir Tahun 1999 tentang Bank Umum Berdasarkan Prinsip syari'ah

Surat Keputusan Direksi Bank Indonesia, Nomor 34/36/Kep/Dir Tahun 1999 tentang Bank Perkreditan Rakyat Berdasarkan Prinsip Syari'ah 